\title{
Role of Organisational Culture in Open Innovation: An Empirical Study of Service Sector Organisations in Sri Lanka
}

\author{
K.A.S.K. Kariyapperuma \\ University of Sri Jayewardenepura, Sri Lanka
}

\begin{abstract}
Innovation underpins the process of bringing novel products and services to market and is critical to a firm's viability, competitive advantage and performance. Open innovation has been proposed as a new paradigm for the management of innovation. Success in this open innovation paradigm offers great benefits to business organisations. Many firms have succeeded in the open innovation paradigm but failures have also been reported. Being a new area of research, not much is known about the factors affecting open innovation. In view of this, the current research was conducted with the aim to study the effects of organisational culture on open innovation. The main purpose of the study was to identify organisational culture types which enable and retard both in-bound open innovation and out-bound open innovation. Cross-sectional data were collected using the survey method from 124 middle and top managers working in finance and information technology sectors in Sri Lanka. The data analysis has been done using the statistical software packages of SPSS and AMOS. Both cluster analysis method and hierarchical multiple regressions were employed to test the hypothesised relationships. Highly integrative culture was found to relate positively to in-bound open innovation. No evidence of a significant relationship between highly integrative organisational culture and outbound open innovation was found. Hierarchy culture related negatively to both in-bound open innovation and out-bound open innovation. This research paper is probably the first empirical study which investigates the
\end{abstract}

Dr. K.A.S.K. Kariyapperuma is a Senior Lecturer at the Department of Business Administration, University of Sri Jayewardenepura, Nugegoda, Sri Lanka. E-mail: seshika@sjp.ac.lk 
role of organisational culture in open innovation in the Sri Lankan context. Practical implications for the managers are given and suggestions are offered for future research building on the findings of this study.

\section{Keywords}

In-bound Open Innovation, Innovation, Open Innovation, Organisational Culture, Out-Bound Open Innovation,

\section{Introduction}

Organisational efforts towards innovation are simultaneously driven by the need, and the opportunity, to improve products, services and processes. OECD (2013) defined innovation as "the process of making changes large and small, radical and incremental, to products, processes and services that results in the introduction of something new for the organisation that adds value to customers and contributes to the knowledge store of the organisation." Since the possibilities of established "something new" that can be improved are effectively infinite, innovation plays a continuous role in every aspect of organisational experience.

Traditionally, innovation has been considered as being solely in the realm of firms' internal activities, such as research and development. Yet, knowledge and innovative ideas are widespread and abundantly available in firms' external environment (Chesbrough, 2003). In this regard, Henry Chesbrough (2003) created the term "open innovation" to acknowledge that in order to increase innovation performance, firms' need to make use of external knowledge more systematically or "purposively" (Chesbrough, 2003). He defined it in 2006 as "the use of purposive inflows and outflows of knowledge to accelerate internal innovation, and to expand the markets for external use of innovation, respectively. It thus comprises both outsidein and inside-out movements of technologies and ideas, also referred to as 'technology acquisition' and 'technology exploitation' (Lichtenthaler, 2008). It suggests that organisations make use of knowledge available in the external environment of their firm and combine knowledge developed inside the firm with knowledge generated through external search efforts (Lichtenthaler \& Lichtenthaler, 2009). Open innovation has been proposed as a new paradigm for the management of innovation (Chesbrough, 2003; Gassmann, 2006). 
As indicated by recent reviews on open innovation, it has become an increasingly important issue of research (Dahlander \& Gann, 2010; Huizingh, 2011; Lichtenthaler, 2011; de Vrande et al., 2010). At the same time, management practice has adopted open innovation (Chesbrough, 2006; Dodgson et al., 2006; Rohrbeck et al., 2009). Previous research has shown that firms benefit substantially from external knowledge integration and the utilization of a diverse set of external partners during the innovation process (Faems et al., 2010; Laursen \& Salter, 2006). However, reaping the benefits of open innovation does not seem to be easy due to several challenges accompany the open innovation processes (Naqshbandi \& Kaur, 2014). Firms may need to develop or implement new practices in order to benefit from open innovation (Dahlander \& Gann, 2010; Foss et al., 2011). Thus it is important to understand how firms' internal organisation and practices exactly can facilitate their efforts to draw benefits from open innovation (Brunswicker, 2011; Chesbrough, 2006).

Recent research encourages the investigation of the application prerequisites, conditions, challenges and barriers of open innovation (Laursen \& Salter, 2006; Van de Vrande et al., 2010). Surprisingly, there is only little empirical research in the existing literature on open innovation, aforementioned factors and the possibilities of companies to align their organisations appropriately. The current body of knowledge on open innovation highlights the importance of organisational culture in aligning organisations to reap benefits from open innovation (e.g. Lichtenthaler, 2011). Extant researches indicate that while favourable organisational cultures make collaborations with external parties more effective, unfavourable cultures can cause problems for collaborations. However, it is unclear that what type of organisational culture enables open innovation, or inhibit it. This unclarity could be attributed to infancy of open innovation research, thereby leaving a clear and fruitful avenue for further theoretical and empirical research. Therefore, the objective of this research is to identify organisational culture types that enables or inhibits open innovation in the Sri Lankan financial and IT (Information Technology) industries.

This research paper provides empirical evidence concerning the relationships between organisational culture and open innovation in a 
developing country setting, Sri Lanka. The data was collected in 2015 from January to May. In Asian context, a few studies on open innovation have emerged. However, no research is documented about open innovation activities in Sri Lanka, specifically in the financial and IT sectors which contributes substantially to the Sri Lankan economy. In addition to the contribution by filling the gap in extant open innovation theory, the findings of this research will help practitioners nurture organisational cultures that enable open innovation and avoid unfavourable organisational cultures that prevent open innovation.

The remaining part of this research paper is organised as follows. Next section discusses the literature pertaining to open innovation and organisational culture. At the end of the next section, the researcher develops hypotheses to show the relationships between different types of organisational cultures and open innovation. Section three describes the research methodology while section four analyses the collected data. Finally, section five and six concludes and discusses the limitations and implications of the research.

\section{Literature Review and Hypotheses Development}

\section{Innovation}

The term innovation comes from Latin's innovare, which means "to make something new" (Tidd et al., 2005). The definition, however, has developed over time and been interpreted very differently (Sauber \& Tschirky, 2006). Innovation has been identified as one of the most important process playing a pivotal role in increasing organisational performance (Hertog et al., 2010). Organisations require innovation in order to experience sustained growth, raise the quality and productivity levels of products and services, respond to changing customer needs and expectations, or stand up to superior competitive offerings (Spohers et al., 2008; Daset al., 2006; Miles, 2005; Consoli, 2009; Consoli \& Elche-Hortelano, 2010). Thus, innovation development is considered as an important organisational goal and organisations follow two main strategies to achieve desired innovative goal; closed innovation strategy and open innovation strategy. 


\section{Open Innovation}

The traditional view of firms' innovation was dominated by the close innovation strategy, an in-house focus and an emphasis on firms' own Research and Development (R\&D) efforts. Firms spent significant resources to create sufficient $R \& D$ capabilities and to exploit the results of these efforts (Chesbrough, 2006). The closed innovation model assumes firms' innovation success roots in the exertion of strong control over their innovation activities and outcomes, ensuring that the maximum benefit of these activities accrue to the originating firm (Chesbrough, 2006; Vanhaverbeke \& Cloodt, 2006). However, with the changes the conditions in which business is conducted have seen, this model is no longer sustainable (Brunswicker, 2011). The increase of labour availability and mobility, the abundance of venture capital, and increased capability levels among external parties, such as suppliers, are among the factors which stirred this development (Chesbrough, 2003). Further, the roles of organisational knowledge and knowledge workers have acquired increasing importance (Savino, 2009) knowledge has become the key resource in the post-industrial society (Bell, 1973). The speed and intensity of change insures both that more information is needed, and that it must be acquired at a progressively faster pace. Accordingly, the maintenance of closed cycles of innovation through rigid internal control has become increasingly difficult (Vanhaverbeke, 2006).

Open innovation describes an approach in which firms involve a wide range - with regard to amount and diversity - of outside actors in their innovation processes in order to leverage or exploit those parties' knowledge (Chesbrough, 2003). Specifications of this open innovation include the engagement in alliances (Rothaermel \& Alexandre, 2009), the integration of customers or users via various methods (Jeppesen, 2005; Piller \& Walcher, 2006), the integration of suppliers, universities, and other research institutions (Laursen \& Salter, 2006), or the interaction with a broader, more general public (Lakhani et al., 2007) up to the developments around community-based innovations (Lakhani \& von Hippel, 2003; von Hippel\& von Krogh, 2003; West \& Lakhani, 2008). All of these examples have in common that external knowledge is utilised for firms' internal innovation processes with the objective of improving firm performance. 


\section{Types of Open Innovation}

Extant research has identified two types of open innovation: in-bound open innovation and out-bound open innovation. Inbound open innovation refers to internal use of external knowledge; while outbound open innovation refers to external exploitation of internal knowledge. In- bound open innovation implies purposive inflow of knowledge or technology exploration relating to innovation activities aimed at capturing and benefiting from external sources of knowledge to enhance current technological developments. On the other hand, out-bound open innovation implies purposive outflows of knowledge, or technology exploitation, meant to leverage existing technological capabilities outside the boundaries of the organisation. Both in-bound and out-bound open innovation relates to the three knowledge processes of knowledge exploration, retention, and exploitation that can be performed either inside or outside a firm's boundaries (Lichtenthaler \& Lichtenthaler, 2009).

\section{Organisational Culture}

Organisational culture has been variously defined (Schein, 1990; Hofstede et al., 1990). Geertz (1973) explains culture as a system of shared symbols. Schein (1993) provides an elaborate definition that culture represents 'a pattern of basic assumptions that was learned by a group as it solved its problems of external adaptation and internal integration, that has worked well enough to be considered valid and therefore, to be taught to new members as the correct way to perceive, think, and feel in relation to these problems.' This definition focuses on external adaptation and internal integration aspects of an organisation's culture. These aspects are in turn based on five cultural values namely: customer orientation, employee development, harmony, responsibility and innovation which were introduced by Tsui, Wang and Xin (2006).

\section{Types of Organisational Culture}

Organisational culture is classified in different ways. The research of Tsui et al. (2006) applied the configuration approach in analyzing the organisational culture of set of organisations. Using aforementioned cultural values, in a cluster analyses the study identified four cultural types with the labels of highly integrative, moderately integrative, market oriented and hierarchy culture. These authors encouraged the use of these culture types in future 
research. Thus, this researcher adopted the Tsui et al. (2006) method in this study to identify organisational culture types by applying cluster analysis on the five cultural values.

\section{Integrative and Hierarchical Organisational Cultures}

Integrative culture is used to refer organisational cultures that have widely shared and strongly held values which address the firm's needs of internal integration and external adaptation (Schein, 1992). These cultures emphasise high standards for performance, innovation and responses to changes in the external environment in turn essential for open innovation. (Tsui et al., 2006). According to Denison and Misra (1995), organisations that care for their customers and are socially responsible tend to be more flexible in dealing with changes in the environment. Integrative culture organisations unite employees by promoting their aspirations to succeed, instilling a purpose for work and strengthening their involvement with the organisation (Chatman \& Jen 1994). Employees in integrative cultures reciprocate with high level of affective commitment, task performance and citizenship behavior.

On the other hand, hierarchical cultures do not emphasise such cultural values when dealing with the customers and the society. There is little participation in decision making. Employees are expected to follow, standards, operating procedures and rules. Organisations with hierarchical cultures achieve goals through formal rules and close supervision. Hence these cultures do not promote innovative behaviors. As a result hierarchical cultures have been found to promote imitation strategies (Naranso-Valancia et al., 2011). These inward-looking cultures were often seen as a barrier for open approaches (Golighty, 2012). They focus least on internal integration of the organisational resources and adaptation of external environment of a firm, emphasis on which is important for the success of open innovation. In light of this discussion, the researcher hypothesised that;

H1: Highly integrative organisational culture relates positively to inbound open innovation

H2: Highly integrative organisational culture relates positively to outbound open innovation 
H3: Hierarchical organisational culture relates negatively to in-bound open innovation

H4: Hierarchical organisational culture relates negatively to out-bound open innovation

Based on the above characteristics and hypotheses the present researcher put forward the study frame work depicted in Figure 1.

\section{Figure 1: The Study Framework}

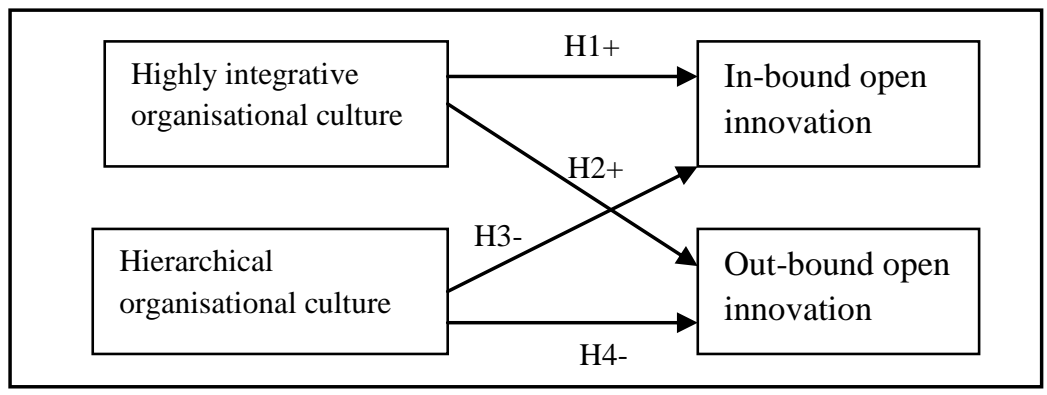

\section{Research Methodology}

\section{Research Design}

A non-experimental, descriptive, co relational design was followed in this study. A cross- sectional field survey method was used to collect the data. Since it was a cross sectional survey, the sample period involved five months in the year of 2015. The unit of analysis in the survey was individual organisations of financial and IT sectors.

\section{Target Population and Sampling}

The target population of this study was the top and middle level managers working in the organisations of Sri Lankan financial and IT sectors. Top and middle level managers were chosen because of their know-how of the strategic direction of the firm. The IT and financial sectors were selected because, adaptation of open innovation is anticipated to be stronger in these two sectors. The organisations are characterised by globalization, technology and knowledge intensity, technology diffusion and knowledge leverage. Thus they were more prone to open innovation adoption. Two sample frameworks were used. The first one was taken from Central Bank 
of Sri Lanka (The list of registered financial organisations- 2015). The second sample framework retrieved from the www.slasscom.lk. In total 200 questionnaires were distributed by e-mail (Google drive database) and in person; 136 were returned. After data coding and entry, 12 responses were found to have more than 10 percent of missing values and were thereafter discarded( Hair et al.,2010).Finally 124 usable responses were used for data analyses. This represents a response rate of 62 percent.

\section{Measurements}

\section{Organisational Culture}

The questionnaire items were derived mainly from previous studies. Organisational culture items were adapted from Tsui et al.(2006). In total 23 items measures organisational culture on this study. The scale of Tsui et al., (2006) measures culture on five dimensions: employee development (5 items), harmony (five items), customer orientation (five items), social responsibility (four items) and innovation (four items). All the items were anchored on a five-point Likert scale ranging from "strongly disagree to strongly agree".

\section{Open Innovation}

Out- bound open innovation was measured with four (items) which were developed by Lichtenthaler (2009). In-bound open innovation was measured using six items (6) taken from the scale developed by Sisodiya (2008).Both dimensions were measured on a 5-point Likert scale ranging from "strongly disagree to strongly agree".

\section{The Pilot Test}

To ensure the reliability and the validity of the scale, a pilot test was conducted using MBA students of the MSc. unit of the Faculty of Management Studies and Commerce, University of Sri Jayewardenepura. Most of the students were studying part time and working full time as middle level managers. Cronbach Alpha was used to measure internal consistency and it was found to be above .7 for all variables thus confirming acceptable reliability of the scale (Hair et al., 2010). 


\section{Data Analysis}

\section{Sample Profile}

The sample of respondents was drawn from two different service industries in Sri Lanka. The Number of respondents varied amongst the industries- 42 percent from finance industry and 57 percent from IT industry. Table 1 shows number of questionnaires collected for the main study from each service industry.

Table 1: Industry wise Distribution of Returned Questionnaires

\begin{tabular}{|l|c|c|}
\hline \multicolumn{1}{|c|}{ Industry } & Frequency & Percentage \\
\hline Insurance & 12 & 0.096 \\
\cline { 2 - 3 } Banking & 16 & 0.12 \\
\cline { 2 - 3 } Other financial services & 25 & 0.20 \\
\cline { 2 - 3 } Finance Industry & $\mathbf{5 3}$ & $\mathbf{0 . 4 2}$ \\
\hline Information Technology & $\mathbf{7 1}$ & $\mathbf{0 . 5 7}$ \\
\hline Total & 124 & 100 \\
\hline
\end{tabular}

Source: Survey Data

Most of the respondents (63.2 percent) occupied middle management positions while 36.8 were top managers, indicating that they were in a good position to describe both organisational culture and the innovation strategy. Majority of the organisations (71.3) had been operating more than five years thus can be considered as quite established.

\section{Screening and Cleaning the Data}

The purpose of this process was to identify outliers and treatments for missing values. Statistical package for social sciences (SPSS) software version 18 was used for this data cleaning and screening process. The statistically insignificant Little's MCAR result of this research indicates that patterns of missing values were completely at random (Tabachnick \& Fidell, 2007). Twelve responses were found to have more than 10 percent of missing values and were thereafter discarded. The mean substitution method was used to substitute the missing values. Standardised scores were used to detect uni-variate outliers and Malonabies distance measures was used to detect the multivariate outliers. Since there are no outliers, all 124 questionnaires were forwarded within the process. 


\section{Testing for Multivariate Assumptions}

The normality is considered to be a fundamental assumption in multivariate analysis (Hair et al., 2011). In this study the methods of visual inspection of P-P plot of the regression standardised residuals and values of skewness and kurtosis were used to measure the normal distribution of data. The distribution of values in the current study shown that all variables were clustered around the straight line of the P-P plot diagrams and all the variables were within the normal range of skewness (i.e. <_ 2, c.f. Hair et al., 2011). The kurtosis statistics which range from -1.131 to $1.516(-2>2)$ show that the data distribution is normal.

\section{Common Method Bias and Non-Response Bias}

In this study, the chances of any potential non-response biasness were computed by assessing the difference through independent sample $t$ test between early and late respondents. The subjective measures of the five dimensions of organisational culture, in-bound open innovation and, outbound open innovation were compared between early respondents (93) and late respondents (31) and found no significant differences between the two groups via independent sample t- test in SPSS ( $\mathrm{P}>.05)$. Thus, non-response bias is not a concern in the present study.

Harman's single factor test was used to assess the common method bias (Podsakoff et al., 2003). All the 33 observed variables were entered into an exploratory factor analysis, using unrotated principal components factor analysis, to determine the number of factors that are necessary to account for the variance in the variables. The exploratory factor analysis carried out using this method revealed the presence of eight distinct factors with eigenvalue greater than 1.0, rather than a single factor. The first (largest) factor did not account for a majority of the variance. Thus, no general factor is apparent, indicating that the data is free from common method bias.

\section{Explanatory Factor Analysis (EFA) and Confirmatory Factor Analysis (CFA)}

Explanatory factor analysis was conducted using principal components analysis (PC) as the extraction method and Varimax with Kaizer normalization method as the rotation method to reduce 23 items measuring organisational culture into small number of factors. The Kaiser-MeyerOlkin (KMO) measure of sampling adequacy was used to examine the 
appropriateness of factor analysis, with high values(0.922) indicating that factor analysis is appropriate (Malhotra, 2004). Bartlett's Test of Sphericity is significant for the construct, and justifies that the construct correlates perfectly with itself. The results of KMO and Bartlett's test of sphericity $(\mathrm{p}<0.001)$ allow to forward data of this study for the EFA.EFA for organisational culture is evaluated, and shown in Table 2.

Table 2: EFA Results of Organisational Culture

\begin{tabular}{|c|c|c|c|c|c|c|}
\hline \multicolumn{6}{|c|}{ Rotated Component Matrix ${ }^{\mathrm{a}}$} & \multirow{3}{*}{ Cronbach's alpha } \\
\hline & \multicolumn{5}{|c|}{ Component } & \\
\hline & 1 & 2 & 3 & 4 & 5 & \\
\hline OC.EmpDe.1 & .526 & & & & & 0.932 \\
\hline OC.EmpDe. 2 & .724 & & & & & \\
\hline OC.EmpDe. 3 & .762 & & & & & \\
\hline OC.EmpDe.4 & .763 & & & & & \\
\hline OC.EmpDe.5 & .783 & & & & & \\
\hline OC.Ha.1 & & & & .513 & & 0.893 \\
\hline OC.Ha.2 & & & & .707 & & \\
\hline OC.Ha.3 & & & & .792 & & \\
\hline OC.Ha.4 & & & & .684 & & \\
\hline OC.Ha.5 & & & & .654 & & \\
\hline OC.CuO.1 & & & & & .553 & 0.821 \\
\hline OC.CuO.2 & & & & & .641 & \\
\hline OC.CuO.3 & & & & & .781 & \\
\hline OC.CuO.4 & & & & & .637 & \\
\hline OC.CuO.5; & & & & & .675 & \\
\hline OC.SoR.1 & & .655 & & & & 0.845 \\
\hline OC.SoR.2 & & .774 & & & & \\
\hline OC.SoR.3 & & .737 & & & & \\
\hline OC.SoR.4 & & .724 & & & & \\
\hline OC.Inv.1 & & & .628 & & & 0.869 \\
\hline OC.Inv.2 & & & .767 & & & \\
\hline OC.Inv.3 & & & .836 & & & \\
\hline OC.Inv.4 & & & .712 & & & \\
\hline $\begin{array}{l}\text { Extraction } \mathrm{Me} \\
\text { Rotation Meth }\end{array}$ & cipal & $\begin{array}{l}\text { pone } \\
\text { aiser }\end{array}$ & $\begin{array}{l}\text { alysis } \\
\text { aliza }\end{array}$ & & & \\
\hline
\end{tabular}

Source: Survey Data

The number of factors generated by EFA is somehow aligned with the basic scale. These five factors explain only 65.289 per cent of total variance, which is considerably high. Thus organisational cultures with all items were 
forwarded to reliability tests for further investigations. All the five factors were highly reliable measurements with reliability coefficients ranging from .82 to .93 because these values were higher than the recommended value 0.7 (Cronbach's, 1951). Thus all the items were forwarded to confirmatory factor analysis (CFA). In addition to the Cronbach's Alpha reliability, CFA compute the composite reliability (CR) and average variance extracted (AVE).The initial model fit index showed a poor fit: $(\mathrm{CMIN} / \mathrm{df}=2.974$; GFI $=0.922:$ AGFI $=0.895 ; \mathrm{CFI}=0.920: \mathrm{RMSEA}=0.085$ ). Though the fit statistics such as GFI, CFI are at acceptable level, the model was modified using suggested modification indices. All the fit statistics of the new model indicated that the model fitted the data acceptably $(\mathrm{CMIN} / \mathrm{df}=1.887$; GFI= 0.976: $\mathrm{AGFI}=0.928: \mathrm{CFI}=0.992: \mathrm{RMSEA}=0.061)$.

Open innovation was measured with two scales: in-bound open innovation and out-bound open innovation. In-bound open innovation was measured with six items and out-bound open innovation was measured with four items. In line with theoretical prediction, open innovation revealed two factors in EFA. However one factor from in-bound open innovation and another one from out-bound open innovation were dropped due to low factor loadings. Without these two items the model explained $58.23 \%$ of the variance with Eigen value more than one. The Bartlett's test of Sphericity was found to be significant and The KMO was acceptable (.838).

Then, open innovation with eight items were forwarded to reliability tests for further investigations. Both scales were highly reliable with reliability coefficients ranging from 0.86 to 0.91 . CFA was conducted for open innovation after removing two items and the final model showed a quite reasonable fit $(\mathrm{CMIN} / \mathrm{df}=1.773$; $\mathrm{GFI}=0.966$ : $\mathrm{AGFI}=0.928: \mathrm{CFI}=$ 0.983: RMSEA $=0.052$ ). 
Table 3: EFA Results of Open Innovation

\begin{tabular}{|c|c|c|c|}
\hline \multicolumn{3}{|c|}{ Rotated Component Matrix $^{\mathrm{a}}$} & \multirow{3}{*}{ Cronbach's alpha } \\
\hline & \multicolumn{2}{|c|}{ Component } & \\
\hline & 1 & 2 & \\
\hline INBOIV.1 & .820 & & 0.912 \\
\hline INBOIV.2 & .765 & & \\
\hline INBOIV.3 & .820 & & \\
\hline INBOIV.5 & .801 & & \\
\hline INBOIV.6 & .867 & & \\
\hline OUBOIV.1 & & .793 & 0.863 \\
\hline OUBOIV.2 & & .788 & \\
\hline OUBOIV.3 & & .796 & \\
\hline
\end{tabular}

Source: Survey Data

\section{Convergent and Discriminant Validity}

Unidimensionality, reliability and validity of the two constructs were assessed. Discriminant validity was measured using Maximum Shared Square Variance (MSV), Average shared squared variance (ASV) and average variance extracted for all variables(AVE). As given in the Table 4, both MSV and ASV are less than AVE for all variables in this study (Hair et al., 2010). Convergent validity was measured using factor loadings, composite reliability and AVE. As seen from the Table 4, all AVE values and factor loadings are greater than 0.5.Composite reliability for all the variables are greater than AVE of each latent variable. Further, composite reliability for all variables is greater than 0.7 .

Table 4: Convergent Validity, Discriminant Validity and Reliability of Measures

\begin{tabular}{|l|l|c|c|c|c|}
\hline Construct & \multicolumn{1}{|c|}{ Dimensions } & AVE & ASV & MSV & CR \\
\hline \multirow{4}{*}{ Open Innovation } & $\begin{array}{l}\text { In-bound open } \\
\text { innovation }\end{array}$ & 0.611 & 0.236 & 0.555 & 0.887 \\
\cline { 2 - 6 } & $\begin{array}{l}\text { Out-bound open } \\
\text { innovation }\end{array}$ & 0.515 & 0.243 & 0.485 & 0.805 \\
\hline \multirow{4}{*}{$\begin{array}{l}\text { Organisational } \\
\text { Culture }\end{array}$} & Employ Development & 0.577 & 0.089 & 0.192 & 0.780 \\
\cline { 2 - 6 } & Harmony & 0.771 & 0.212 & 0.585 & 0.931 \\
\cline { 2 - 6 } & Customer Orientation & 0.649 & 0.053 & 0.298 & 0.880 \\
\cline { 2 - 6 } & Social Responsibility & 0.611 & 0.245 & 0.555 & 0.903 \\
\cline { 2 - 6 } & Innovation Orientation & 0.654 & 0.054 & 0.298 & 0.881 \\
\hline
\end{tabular}

Note: Average Variance Extracted (AVE), Average Shared Squared Variance (ASV) Maximum Shared Squared Variance (MSV) and Composite Reliability (CR) 


\section{Cluster Analysis}

A cluster analysis is performed on the five dimensions of organisational culture obtained from EFA and confirmed by CFA. K-means procedure was used and results of three-cluster, four-cluster and five-cluster solutions were compared and examined. F-test has been used to compare these statistical models, in order to identify the model that best fit the population from which the data were sampled. The three cluster solution (Table 5) has been selected as the most interpretable solution and it was in line with the past studies including the original study of Tsui et al. (2006). In line with the past studies these three clusters were named as highly integrative culture (high focus on both internal integration and external adaptation), moderately integrative culture (good scores on all dimensions but less than the highly integrative culture), and finally hierarchy culture (low score on all dimensions). As shown in the Table below, there are 39 organisations with highly integrative organisational cultures, forty four organisations with moderately integrative cultures and forty one organisations with hierarchy cultures. These three clusters were turned into dummy variables in a way that they could directly enter into the hierarchical multiple regressions since they were not continuously measured variables.

Table 5: Organisational Culture Types

\begin{tabular}{|l|c|c|c|c|c|c|c|c|c|c|}
\hline Dimensions & \multicolumn{3}{|c|}{$\begin{array}{c}\text { Highly Integrative } \\
\text { Culture }\end{array}$} & \multicolumn{3}{c|}{$\begin{array}{c}\text { Moderately } \\
\text { Integrative Culture }\end{array}$} & \multicolumn{2}{c|}{ Hierarchy Culture } & F-test \\
\hline & Mean & SD & N & Mean & SD & N & Mean & SD & N & \\
\hline $\begin{array}{l}\text { Employ } \\
\text { development }\end{array}$ & 4.32 & 0.46 & 39 & 4.01 & 0.56 & 44 & 3.28 & 0.61 & 41 & $175.34^{*}$ \\
\hline Harmony & 4.45 & 0.38 & 39 & 3.98 & 0.59 & 44 & 3.31 & 0.56 & 41 & $203.82^{*}$ \\
\hline $\begin{array}{l}\text { Customer } \\
\text { orientation }\end{array}$ & 4.27 & 0.48 & 39 & 4.02 & 0.46 & 44 & 3.45 & 0.53 & 41 & $87.21^{*}$ \\
\hline $\begin{array}{l}\text { Social } \\
\text { Responsibility }\end{array}$ & 4.41 & 0.36 & 39 & 3.91 & 0.43 & 44 & 3.51 & 0.52 & 41 & $227.59^{*}$ \\
\hline Innovation & 4.02 & 0.49 & 39 & 3.92 & 0.51 & 44 & 3.02 & 0.54 & 41 & $215.23^{*}$ \\
\hline Total & 124 & & 39 & & & 44 & & & 41 & \\
\hline
\end{tabular}

Source: Survey Data

Note: ${ }^{*} \mathrm{p}<0.01$ 


\section{Hypotheses Testing and findings}

The multiple regression technique has been used to test the hypotheses of this research study and the results are shown in Table 6 and Figure 2. The results indicates that highly integrative culture positively predicts in bound open innovation $(\beta=0.433, p<0.01)$ while hierarchy culture relates to it negatively $(\beta=-0.143, p<0.01)$. Hence $\mathrm{H} 1$ and $\mathrm{H} 3$ are fully supported. Further, it was found that highly integrative culture does not influence outbound open innovation since the relationship between these two variables were statistically insignificant. However, the results indicate that hierarchy culture negatively influence out-bound open innovation $(\beta=-0.154$, $\mathrm{p}<0.05)$. Thus, Hypotheses two (H2) is not supported while hypotheses four (H4) is fully supported.

Table 6: Results of Multiple Regression

\begin{tabular}{|l|c|c|c|c|c|c|}
\hline \multirow{2}{*}{$\begin{array}{l}\text { Criterion } \\
\text { Variable }\end{array}$} & \multicolumn{3}{|c|}{ In-bound Open Innovation } & \multicolumn{3}{|c|}{$\begin{array}{c}\text { Out-bound Open } \\
\text { Innovation }\end{array}$} \\
\cline { 2 - 7 } & \multicolumn{2}{|c|}{ Standardised coefficients } & \multicolumn{2}{|c|}{ Standardised coefficients } \\
\hline $\begin{array}{l}\text { Predictor } \\
\text { Variables }\end{array}$ & $\mathrm{B}$ & $\begin{array}{c}\text { Std. } \\
\text { error }\end{array}$ & $\mathrm{t}$ & $\mathrm{B}$ & $\begin{array}{c}\text { Std. } \\
\text { error }\end{array}$ & $\mathrm{t}$ \\
\hline $\begin{array}{l}\text { Highly } \\
\text { Integrative } \\
\text { Culture }\end{array}$ & $0.433^{* *}$ & 0.064 & 11.421 & -0.342 & 0.82 & -0.264 \\
\hline $\begin{array}{l}\text { Hierarchy } \\
\text { Culture }\end{array}$ & $-0.143^{* *}$ & 0.087 & -3.215 & $-0.154 *$ & 0.083 & -2.864 \\
\hline
\end{tabular}

$* * \mathrm{p}<0.05 ; * * * \mathrm{p}<0.01$

${ }^{a}$ Moderately integrative culture is the reference category for the dummy variables

Figure 2: Findings of the Research with Framework

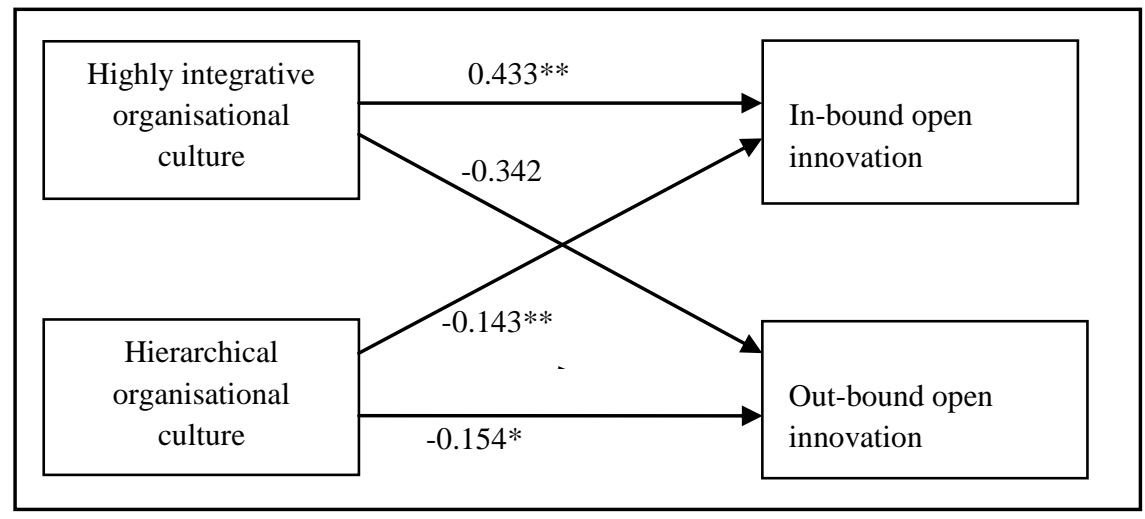

$* * \mathrm{p}<0.05 ; * * * \mathrm{p}<0.01$ 


\section{Discussion}

\section{Organisational Culture and In-bound Open Innovation}

Organisational culture has been identified as very important element which supports innovation by creating an organisational climate that institutionalises innovation. As mentioned by Russel (1989), by focusing attention on innovation, a supportive culture helps to motivate and sustain the complex, interactive process of social exchange necessary for successful innovation. In this study two (2) hypotheses were formed to show the relationships between organisational culture and in-bound open innovation. Hypothesis one proposed a positive relationship between highly integrative culture and in-bound open innovation. The findings of this study indicate that this hypothesis is supported. Therefore, it can be concluded that highly integrative culture in the financial and information technology sector facilitated in-bound open innovation. Hypothesis three (H3) hypothesised a negative relationship between hierarchy culture and in-bound open innovation. The results of this research indicate that this hypothesis is supported as well. Therefore, it can be concluded that hierarchy culture in the financial and IT organisations did not facilitate in-bound open innovation. In fact, presence of hierarchy culture in these organisations negatively impacted facilitation of in-bound open innovation.

Organisational culture has been identified as a major challenge when adopting open innovation (Verbano et al., 2011). In relation to the closed innovation paradigm, many empirical studies provide evidence of a significant relation between organisational culture and innovation (e.g. Chang \& Lee, 2007; Naranjo-Valencia et al., 2011). This current study investigated the link between organisational culture and innovation in the open innovation paradigm. Due to the novelty of the concept of open innovation (Maria et al., 2009), there are no empirical studies that can be directly related to the findings of this study. However, authors have pointed towards the significance of organisational culture in the open Innovation paradigm (e.g. Golightly et al., 2012).

These findings - that is, highly integrative culture impacting in-bound open innovation strongly and positively while hierarchy culture having a strong negative impact on In-bound open innovation - seem to be quite logical. Witzeman et al. (2006) state that the more external innovation is 
sourced by a firm, the more systems, processes, values and culture also needed to be transformed. Open innovation demands a shift from the Not Invented Heresyndrome - a common barrier to its adoption (Golightly et al., 2012) - to the Invented Anywhere approach. Creating a culture that values outside competence and know-how is crucial for open innovation practice (Gassmann et al., 2010). For a firm to make this shift in their approach, organisational culture plays a critical role as it is a critical means for firms to integrate internal processes and to adapt to the external environment (Denison \& Mishra, 1995). The firms with integrative cultures have widely shared and strongly held values that address the firm's needs of internal integration and external adaptation. On the contrary, firms with Hierarchy culture lay a low level of emphasis on these values (Cameron \& Freeman, 1991). Hierarchy culture in firms impedes in-bound open innovation because such a culture focuses least on internal integration and external adaptation, emphasis on which is critical for the success of in-bound open innovation. Embarking thus on the open innovation journey involves problems of setting up structures for open innovation and making changes (Maria et al., 2009); and since firms may not be used to evaluate external innovation, managing such external innovations may involve many challenges (Fetterhoff \& Voelkel, 2006). A highly integrative culture, based on values focusing internal integration and external adaptation, can clearly help in tackling such challenges and facilitate in-bound open innovation.

\section{Organisational Culture and Out-bound Open Innovation}

Two (2) hypotheses of this research related to the relationships between organisational culture and out-bound open innovation. Hypothesis two (H2) proposed a positive relationship between highly integrative culture and outbound open innovation. The results of this research indicate that this hypothesis is not supported. Therefore, it can be concluded that highly integrative culture in the selected organisations does not facilitate out-bound open innovation. Hypothesis four (H4) proposed a negative relationship between hierarchy culture and out-bound open innovation. The findings of this research indicate that this hypothesis is supported. Therefore, it can be concluded that hierarchy culture in organisations stifle out-bound open innovation. These findings indicate that highly integrative organisational culture does not play any role in out-bound open innovation. It seems that hierarchy culture retards out-bound open innovation for the same reasons it 
retards in-bound open innovation because it places less importance on the cultural values that addresses a firm's needs of internal integration and external adaptation.

\section{Managerial Implications}

The findings of this research indicate that highly integrative organisational culture facilitate in-bound open innovation and hierarchy culture retards both in-bound open innovation and out-bound open innovation. The results bring deep insights for managers striving to promote open innovation within their organisations. It shows that managers can succeed in the open innovation paradigm by creating highly integrative organisational cultures. Further it indicates that managers should endeavor to avoid hierarchical culture. Findings of this study recommend promotion of highly integrative culture in financial sector and IT sector organisations so that a free flow of ideas and initiatives is possible horizontally and vertically. Meanwhile they should discourage all the aspects of hierarchy culture.

\section{Research Limitations and Future Research}

Although this study has produced interesting findings in terms of open innovation paradigm, these findings carry important limitations which are relevant for future research, as detailed below. The data was collected from 124 respondents. Additional research is essential to target a large sample as a means of increasing statistical power and more conclusively establishing the robustness of the findings explored in the current study. Further, the researcher served only the financial sector and information technology sector organisations in Sri Lanka, making the findings not completely relevant and generalizable to other sectors of the service industry and the manufacturing sector. Thus the framework of this study can be tested in different industry settings and different country settings. In terms of methodology, this study applied pure positivistic research methodology. In the future, this can be tested in neo-positivistic research domain of mix method (qualitative study followed by a quantitative method or vice versa). This might help uncover the reasons for certain issues such as insignificant relationship between highly integrative organisational culture and out-bound innovation. Finally future research can test for the mediating and moderating role of several variables in the relationships studied in this study. 


\section{Acknowledgement}

This paper was presented at the 10th International Research Conference on Management and Finance (IRCMF) held at University of Colombo on $27^{\text {th }}$ November 2015. I would like to acknowledge the reviewers and other academics for their valuable comments and guidance in improving this research paper.

\section{References}

Cameron, K.S., \& Freeman, S.J. (1991). Cultural congruence, strength, and type: Relationships to effectiveness. Research in Organizational Change and Development, 5(1), 23-58.

Chang, S.C., \& Lee, M.S. (2007). The effects of organizational culture and knowledge management mechanisms on organizational innovation: An empirical study in Taiwan. The Business Review, 7(1), 295-301.

Chatman, J.A., \& Jehn, K. A. (1994). Assessing the relationship between industry characteristics and organizational culture: How different can you be? Academy of Management Journal, 522-553.

Chesbrough, H. (2003). The era of open innovation. MIT Sloan Management Review. 44, 35-41.

Chesbrough, H. (2011).Bringing open innovation to services. MIT Sloan Management Review. 52, 85-90

Chesbrough, H., \& Crowther, A.K. (2006). Beyond high tech: Early adopters of open innovation in other industries. $R \& D$ Management. 36, 229-236.

Consoli, D. (2009). An evolutionary perspective of health innovation systems. Journal of Evolutionary Economics, 19(2), 297-319.

Consoli, D., \& Elche-Hortelano, D. (2010). Variety in the knowledge base of business service sectors. Research Policy, 39: 1303-1310.

Dittrich, K., \& Duijsters, G.M. (2007). Networking as a means to strategic change: The case of open innovation in mobile telephony. Journal of Product Innovation Management,24(6),510-521.

Dahlander, L., \& Gann, D.M. (2010). How open is innovation? Research Policy,39, 699-709.

Denison, D. R., \& Mishra, A. K. (1995). Toward a theory of organizational culture and effectiveness. Organization Science, 6(2), 204-223.

Dodgson, M., Gann, D., \& Salter, A.(2006). The role of technology in the shift towards open innovation: The case of Procter $\&$ Gamble. $R \& D$ Management.36, 333-346.

Faems, D., de Visser, M., Andries, P., \& Van Looy, B. (2010). Technology alliance portfolios and financial performance: Value-enhancing and cost-increasing effects of open innovation. Journal of Product Innovation Management, 27(6), 785-796. 
Fetterhoff, T.J., \& Voelkel, D. (2006). Managing open innovation in biotechnology. $R \& D \quad$ Management Research-Technology Management, 49(3), 14-18.

Gassmann, O. (2006). Opening up the innovation process: Towards an agenda, 36, 223-228

Gassmann, O., Enkel, E., \& Chesbrough, H. (2010). The future of open innovation. $R \& D$ Management, 40(3), 213-221.

Golightly, J., Ford, C., Sureka, P., \& Reid, B. (2012). Realizing the value of open innovation. London: Big Innovation Centre (The Work Foundation and Lancaster University). Retrieved July 25, 2015 from: www.biginnovationcentre.com/Assets/Docs/Reports/Realising_theVa lue_ofOI_FINAL.pdf

Hair, J. F. Jr., Black, W. C., Babin, B. J., Anderson, R. E., \& Tatham, R. L., (2010). Multivariate data analysis: Global perspective, 7th ed., Upper Saddle River: Pearson Prentice Hall.

Hertog, P., van der Aa, W., \& de Jong, M. W. (2010). Capabilities for managing service innovation: Towards a conceptual framework, Journal of Service Management, 21(4), 490-514.

Hofstede, G., Neuijen, B., Ohayv, D.D., \& Sanders, G. (1990). Measuring organizational cultures: A qualitative and quantitative study across twenty cases. Administrative Science.35, 286-316 (1990)

Laursen, K., \& Salter, A. (2006). Open innovation: The role of openness in explaining innovation performance among U.K. manufacturing firms. Strategic Management Journal, 27(2), 131-150.

Lichtenthaler, U. (2009). Outbound open innovation and its effect on firm performance: examining environmental influences. $R \& D$ Management, 39, 317-330.

Lichtenthaler, U. (2011). Open innovation: Past research, current debates, and future directions. Academic Management Perspective.25, 75-93.

Malhotra, N. K. (2004). Marketing research: An applied orientation. New Jersey: Pearson Prentice Hall.

Maria, E., Tobias, F., \& Susanne, O. (2009).Exploring the field of open innovation. European Journal of Innovation Management, 12(3), 326-345.

Miles, I. (2008). Patterns of innovation in service industries. IBM Systems Journal, 47(1), 115-128.

Naranjo-Valencia, J.C., Jiménez-Jiménez, D., \& Sanz-Valle, R. (2011). Innovation or imitation? The role of organizational culture. Management Decision, 49(1), 55-72.

Naqshbandi,, M.M., \& Kaur, S. (2011). Factors affecting open innovation: Evidence from Malaysia. Australian Journal of Basic Applied, 5, 2783-2795 
Naqshbandi, M.M., \& Kaur, S. (2011). A study of organizational citizenship behaviours, organizational structures and open innovation. International Journal of Business Social Sciences, 2, 182-193.

Naqshbandi, M.M., \& Kaur, S. (2014). Do managerial ties support or stifle open innovation? Industrial Management Data Systems.114, 652675.

OECD (2013), OECD economic outlook, Vol. 2013/1, OECD Publishing.

Schein, E.H.(1992).Organizational Culture and Leadership. Jossey-Bass: San Francisco.

Sisodiya, S. R. (2008). The effect of open innovation on new product development success: The moderation of interfirm relational knowledge stores and social network characteristics. (Doctoral dissertation), Washington State University, Washington, UnitedStates.Retrievedfromhttp://proquest.umi.com/pqdweb?did=162 $7876311 \&$ sid $=1 \&$ Fmt $=2 \&$ clientId $=18803 \&$ RQT $=309 \&$ VName $=P Q$ $\mathrm{D}(1627876311)$

Sauber, T., \& Tschirky H. (2006). Structured creativity, Palgrave Macmillan.

Spohrer, J., \& Maglio, P.P. (2008). The emergence of service science: Toward systematic service innovation to accelerate co-creation of values. Journal of Production and Operations Management,17(3), 238-246.

Tabachnick, B. G., \& Fidell, L. S. (2007). Using multivariate statistics. NewYork: Allyn \& Bacon.

Teece, D.J., Pisano, G., \& Shuen, A. (1997). Dynamic capabilities and strategic management. Strategic Management Journal, 18, 509-533.

Tidd, J., Bessant, J., \& Pavitt, K. (2005). Managing innovation: Integrating technological, market and organizational change (3rd ed.). New York: John Wiley \& Sons.

Tsui, A.S., Wang, H., \& Xin, K.R. (2006). Organizational culture in China: An analysis of culture dimensions and culture types. Management Organizational Review.2, 345-376.

Von Hippel, E. (2010). Comment on 'Is open innovation a field of study or a communication barrier to theory development?Technovation,30, 555.

Verbano, C., Crema, M., \& Venturini, K. (2011). Integration and selectivity in open innovation: An empirical analysis in SMEs. Globalization, 90(5), 32.

Witzeman, S., Slowinski, G., Dirkx, R., Gollob, L., Tao, J., Ward, S., \& Miraglia, S. (2006). Harnessing external technology for innovation. Research-Technology Management, 49(3), 19-27. 
